認定医症例報告

治療義歯による総義歯補経で顎関節症および随伴症状が改善された 1 症例

遠藤 憲史

\title{
A Case of Temporomandibular Dysfunction and Accessory Symptoms Improved by Treatment Dentures
}

Norifumi Endo

抄 録

症例の概要 : 患者は 64 歳女性で開口困難および咀嚼困難を主訴として来院した。顎関節症状の改善には 理学療法を行った。顎堤粘膜の改善と咀嚼機能の回復には治療義歯を応用し, 顎関節症状および咀嚼機能 が改善された時点で，治療義歯および咬合面形態を最終義歯に移行した。その結果，開口困難は改善し， 満足のいく咀嚼機能をもつ総義歯を装着することができた.

考察：顎関節症の治療には，顎関節部に加わる負荷のコントロールが重要であることは知られている。そ こで治療義歯によって負荷のコントロールと床下粘膜の改善が行われ，良好な結果が得られた。 結論：治療義歯を用いることによって，顎関節機能と咀嚼機能を同時に改善することができた.

和文キーワード

開口困難，顎関節症，治療義歯

\section{ABSTRACT}

Patient: A 64-year-old woman visited our hospital with her chief complaint being difficulty in mouth opening and chewing. Physical therapy was initiated to alleviate the temporomandibular dysfunction, and treatment dentures were applied to improve the ridge mucosa and chewing function. The occlusal form of the treatment dentures was switched to the final dentures when the temporomandibular joint symptoms and chewing function were improved. This resulted in improved mouth opening and the introduction of complete dentures with satisfactory chewing function.

Discussion: Appropriate control of the load to the temporomandibular joint is known to be important for treating temporomandibular arthrosis. In the present case, use of the treatment dentures allowed the load to be controlled, and it improved mucosa under the dentures, resulting in satisfactory clinical results.

Conclusion: The use of treatment dentures improved both the temporomandibular and chewing functions.

\section{Key words}

mouth opening difficulty, temporomandibular arthrosis, treatment dentures

東京支部（遠藤歯科医院）

日本大学歯学部歯科補経学教室総義歯補綴学講座

Tokyo Branch (ENDO Dental Clinic)

Department of Complete Denture Prosthodontics, Nihon University School of Dentistry

受付 : 2011 年 1 月 7 日/受理 : 2011 年 6 月 14 日

Received on January 7, 2011/Accepted on June 14, 2011 


\section{I. 緒言}

総義歯補経において顎関節症状の解消および床下粘膜 の改善は装着者が良好な咀嚼機能を営むうえで必須な要 素である。

これらの改善要素を有する症例に対して治療義歯を応 用することによって安定した予後が得られたので報告する。

\section{II. 症例の概要}

患者：初診時年齢 64 歳, 女性.

初診：2000 年 8 月.

主訴：口が開きにくく，入れ歯も痛くて噛めない.

現病歴： 2 年前上・下総義歯を他医院で製作し，その 後, 開口障害ならびに左側耳前部の疼痛が発生した。 上 顎総義歯は，装着後 1 力月ほどではずれやすくなり， 落ちないようにいつも意識的にくいしばっていた。

下顎顎堤左側臼歯部と前歯部粘膜に潰瘍による疼痛に 対して義歯の調整を数回にわたり受けたが，まったく症 状の改善がみられず，当歯科を受診した。

現症：口腔内所見は上・下顎無歯顎，切歯乳頭前方部 煩側に骨吸収，下顎左側顎舌骨筋線部および前歯部粘膜 に潰瘍性の裖瘡を認める (図 1)。

関節雑音は左側にて低音のクレピタス，開口障害およ び左側に開口時遷延性の痛みがあった。

6 自由度下顎運動測定装置ナソヘキサグラフ $(\mathrm{GC}$ 社 製，東京，日本）にて検査を行ったところ，左側下顎頭 の運動量は右側に比較して少なく，切歯部はやや左側に 開口時 S 字状の軌跡となった (図 2).

$\mathrm{X}$ 線所見 : パノラマ X 線では左側下顎頭前方部は嘴 状の形態で頭頂部は扁平化している，また辺縁部は不透 過増生があり，側頭骨の下顎窩には全体的な吸収像が認 められる(図 3 )。

パノラマ 4 分割写真では下顎頭の扁平化および左側 下顎頭の前方への移動量が左に比べ少ない（図 4).

O-CT では下顎頭，下顎䆚の形態に関して以下の所見 を得た（O-CT の撮影および読影は日本大学歯学部放射 線学教室による).

左側：下顎頭前方か嘴状の形態をとっているが，特に皮 質骨肥厚などはみられず,頭頂部は扁平化している(図5).

右側：特に異状所見はみられない(図 6)。

下顎窩最被薄部の肥厚：左側；あり，右側；なし。

下顎頭の形態分類 (Yale) : 左側; convex, 右側; flat ${ }^{1)}$. 診断：左側顎関節症 IV 型の無歯顎.

治療方針：以上の所見により開口障害は理学療法によ

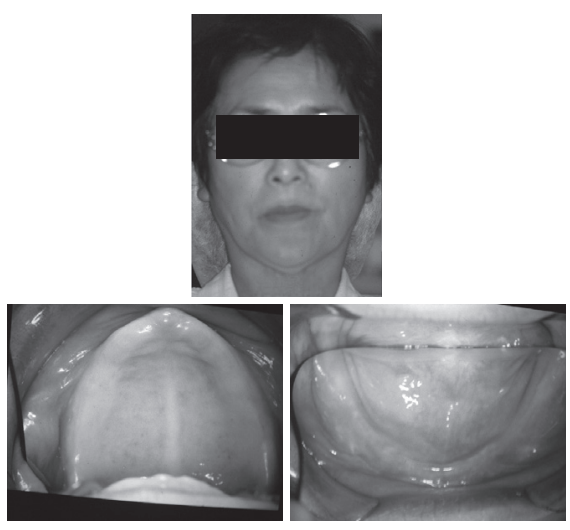

図 1 Intraoral and facial views at first examination 初診時の顔貌と口腔内

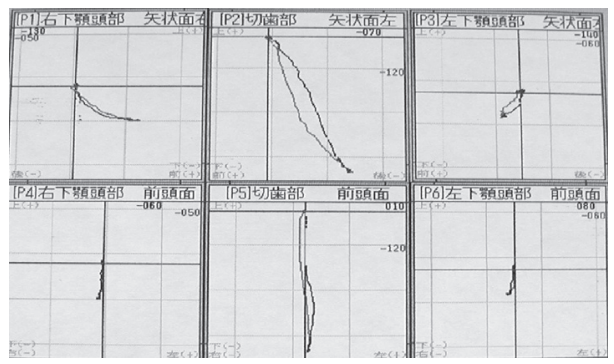

図 2 Maximum open-close mandibular border movement recorded using a six-degree-of-freedom jaw tracking device at first examination 初診時の 6 自由度下顎運動測定装置による最大開閉 口下顎運動軌跡

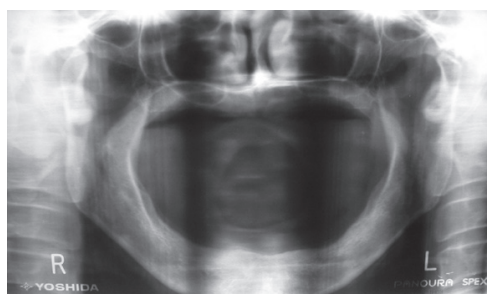

図 3 Panoramic radiography at first examination 初診時のパノラマX X 線写真
R（右）

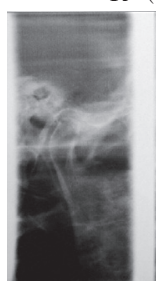

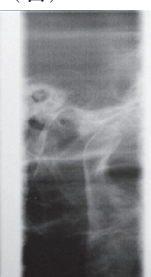

$\mathrm{L}$ (左)

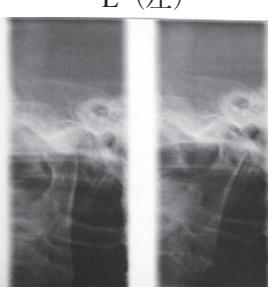

図 4 Four fractional panoramic radiographs of TMJ at first examination 初診時のパノラマ 4 分割写真

り, 疼痛の解消は薬物療法にて行う。顎関節症を伴う咀 嚼障害および義歯不適合による粘膜組織の炎症を治療義 


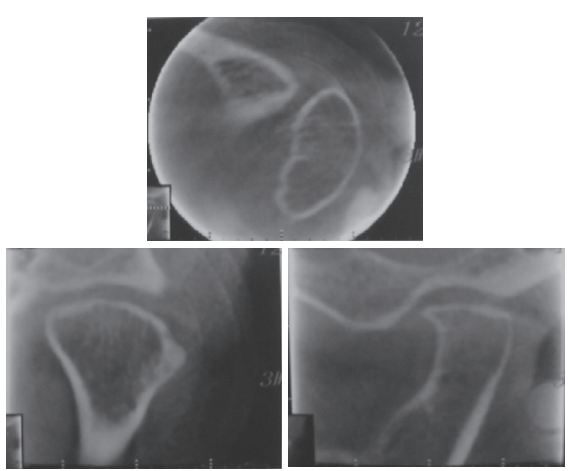

図 5 (Left) X-ray-computed orthotomograph of TMJ （左）顎関節断層 O-CT 写真

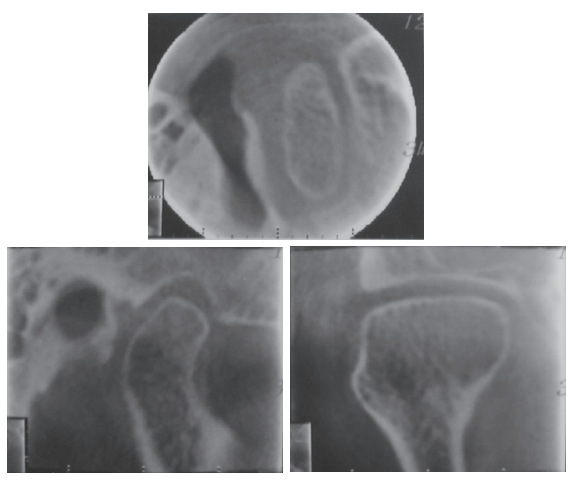

図 6 (Right) X-ray-computed orthotomograph of TMJ （右）顎関節断層 O-CT 写真

歯にて改善，同時に咬合の安定，顎関節への負荷のコン トロールを考慮する。

\section{III. 治療内容と経過}

顎関節の疼痛の解消には薬物療法として消炎鎮痛剤の 投与，開口障害治療に対しては理学療法として超音波 (ITO-US700) $1 \mathrm{MHz}, 1.0 \mathrm{w} / \mathrm{cm}^{2} 10 \mathrm{~min}$., TENZ （ITO-120Z）を咬筋に対して $10 \mathrm{~min}$. 使用した。また 同時に運動療法も行った ${ }^{2)}$.

義歯不適合期間が長いことから，咀嚼筋群のトーヌス の破綻，顎粘膜の組織の炎症および習慣性の偏心咬合位 の是正を図るべく，下顎治療義歯の臼歯部咬合面をフラ ットテーブルにした. 粘膜調整を弾性リベース材にて適 宜行い，床下粘膜部位からの痛みの発生を抑制した。そ して咀嚼, 燕下のリハビリテーションを行った。

左耳前部の疼痛は治療開始後 2 週間で解消されたの で, 薬物および理学療法は中止した。

治療義歯装着後 5 力月で顎関節症状も安定した。また 咀嚼, 発音, 嚥下機能に対して, 患者自身の満足が得られ たことにより,治療義歯の目的が達成されたと判定した ${ }^{3)}$.

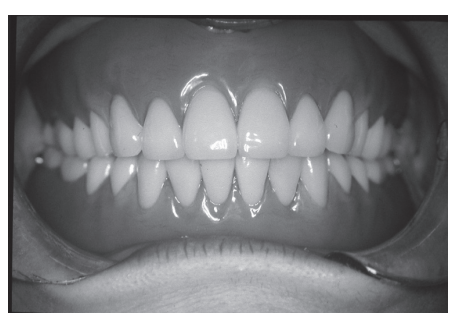

図 7 Intraoral views after insertion of the final dentures 最終義歯装着所見

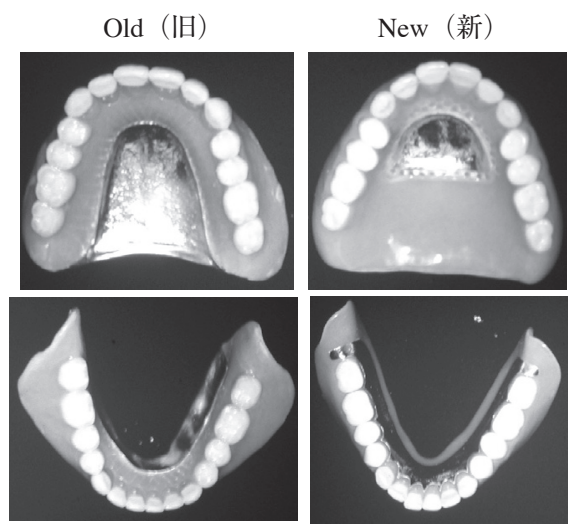

図 8 Comparison of new dentures with old dentures 新旧義歯比較写真

ここで治療義歯により動的印象，咬合採得，人工歯再 選択（患者の希望再確認のため）を行い，最終義歯の完 成は 2001 年 2 月に至った（図 7)。上顎の最終義歯は 舌感覚を考慮して金属床（チタン）としたが，経時的骨 変化に対応すべく旧義歯に比べ金属部分は小さくして, 口蓋中央部のみ金属タッチとした ${ }^{4)}$.

下顎は義歯床下粘膜面は全面レジンとし，舌側面のみ金 属(チタン)にして骨変化に対応できる設計にした(図 8).

最終義歯装着後 4 力月では顎関節症の症状はなく, 義歯と床下粘膜の異常は認められなかった。再来院時は 運動療法の確認と指導を行った. 10 力月後においても 異常は認められなかった。装着後 1 年 4 力月後の経過 観察時においては，下顎義歯の右側床下粘膜に発赤が認 められたので，早期接触の除去と発赤上部義歯床の削除 調整を行って改善した。

義歯装着後 3 年でも顎関節症状や咀嚼困難等の症状 再発はなく安定していた（図9).

装着後 4 年の経過観察時のパノラマX線写真（図 10）では，骨の変化は認められなかった（図 11)。パ ノラマ 4 分割法所見では, 下顎頭は右側に比較して, 左側下顎運動域が少ない.しかし O-CT 所見で画像の 変化は認められなかった（図 12).

以上のように，3 年 4 力月にわたる経過観察において 初診時の主訴である顎関節症の症状や，咀嚼困難といつ 


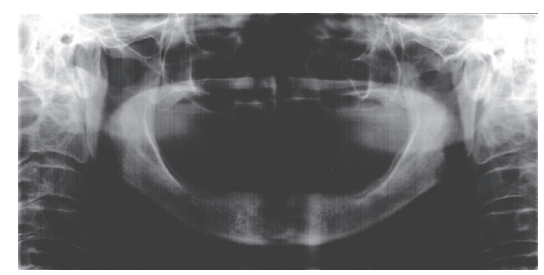

図 9 Panoramic radiograph three years after treatment 治療 3 年後のパノラマX $\mathrm{X}$ 線写真

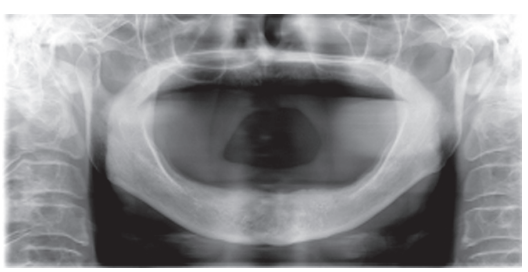

図 10 Panoramic radiograph four years after treatment 治療 4 年後のパノラマX $\mathrm{X}$ 線写真
$\mathrm{R}$ (右)
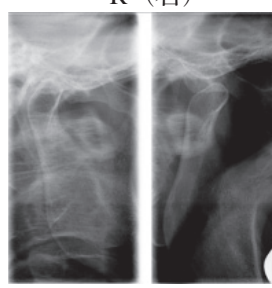

$\mathrm{L}$ (左)

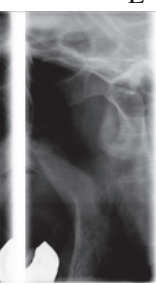

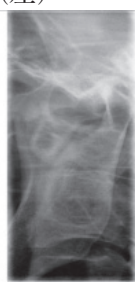

図 11 Four fractional panoramic radiographs of TMJ four years after treatment 治療 4 年後のパノラマ 4 分割写真

た症状の再発はなく，良好な状態を保っている.

\section{IV. 考 察}

本症例では治療義歯により, 過剩な負荷のコントロー ルを行い, 生体力学的に顎関節への負荷を少なくし，義 歯床下粘膜は軟質義歯裏装材にて痛みのない状態を確保 して，咬合の安定をはかった。また顎関節症の急性期に は薬物, 理学療法を行い, 痛みの解消をめざした。その 後は患者自身による負荷のコントロールを継続した。

これらの方法によって本症例の顎関節症および咀嚼機 能障害の改善は, (1)治療義歯の効果, (2)理学療法の効果, (3)薬物療法の効果, (4)運動療法の効果, (5)精神の安寧 ${ }^{5)}$, (6)自然治癒, などの相乗効果によって達成されたものと 思われる。

\section{V. 結 論}

本症例では治療義歯によって, 咬合の安定および粘膜
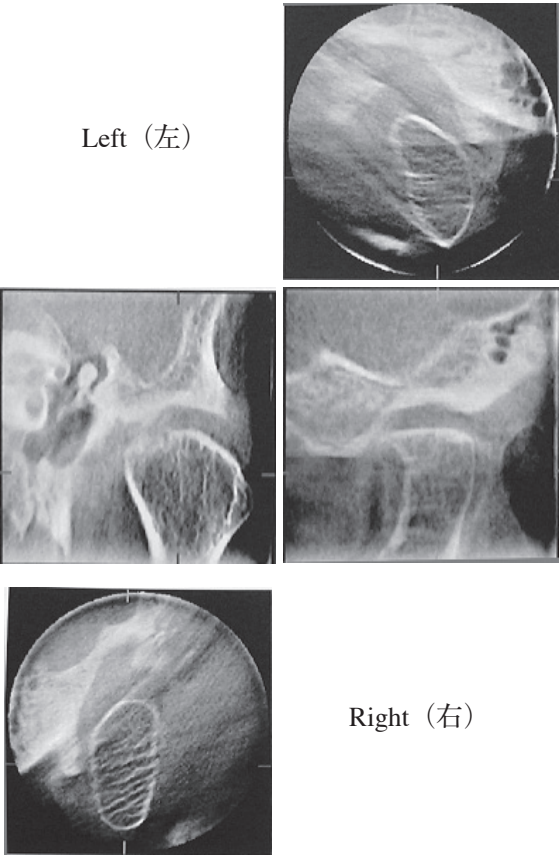

Right（右）
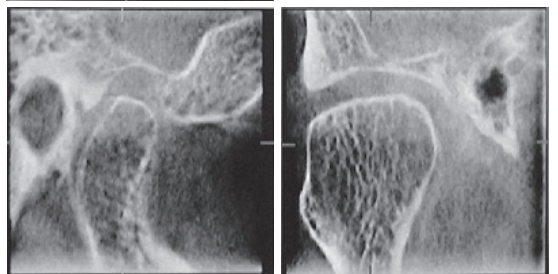

図 12 Left and right X-ray-computed orthotomographs of TMJ four years after treatment 治療 4 年後の左・右顎関節断層 O-CT 写真

の健全化が図られるとともに，理学運動療法によって， 顎関節症および随伴症状が改善されたものと思われる。

文献

1）杉崎正志。顎関節の臨床，大西正俊，渡辺誠，飯塚忠彦 ほか監修，顎関節症。京都 : 永末書店 ; 2003, 36-37.

2）和嶋浩一.TMD の症状とその原因. Charles McNeill 監修, TMD を知る。東京：クインテッセンス出版； 1997, 35-43.

3）深水皓三. 模型から口腔内をよむ. 大野淳一，加藤武彦， 堤嵩詞編。目で見るコンプリートデンチャー、東京：医 歯薬出版；1994, 118-119.

4) David MW, MacGregor AR. Designing Complete Dentures. Philadelphia: W. B. Saunders Company; 1976, 26-27.

5）芦原 睦。心でおきる身体の病，東京：講談社；1994, 103-111.

著者連絡先 : 遠藤 憲史

干 131-0043 東京都墨田区立花 5-26-10

Tel: 03-3618-3836

Fax: 03-3617-2211

E-mail : endo-cmd@mua.biglobe.ne.jp 